Article

\title{
Growth Performance, Eating Behavior, Digestibility, Blood Metabolites, and Carcass Traits in Growing-Finishing Fat-Tailed Lambs Fed Different Levels of Dietary Neutral Detergent Fiber with High Rumen Undegradable Protein
}

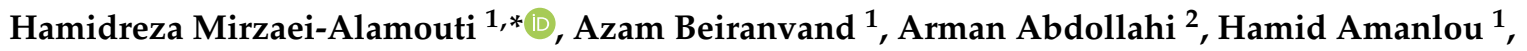 \\ Amlan Kumar Patra ${ }^{3}$ (D) and Jörg R. Aschenbach $4, *$ (D)
}

Citation: Mirzaei-Alamouti, H.; Beiranvand, A.; Abdollahi, A.; Amanlou, H.; Patra, A.K.; Aschenbach, J.R. Growth Performance, Eating Behavior, Digestibility, Blood Metabolites, and Carcass Traits in Growing-Finishing Fat-Tailed Lambs Fed Different Levels of Dietary Neutral Detergent Fiber with High Rumen Undegradable Protein. Agriculture 2021, 11, 1101. https://doi.org/10.3390/ agriculture11111101

Received: 30 August 2021 Accepted: 2 November 2021 Published: 5 November 2021

Publisher's Note: MDPI stays neutral with regard to jurisdictional claims in published maps and institutional affiliations.

Copyright: (c) 2021 by the authors. Licensee MDPI, Basel, Switzerland. This article is an open access article distributed under the terms and conditions of the Creative Commons Attribution (CC BY) license (https:// creativecommons.org/licenses/by/ $4.0 /)$.
1 Department of Animal Sciences, Faculty of Agriculture, University of Zanjan, Zanjan 45371-38791, Iran; azam.beyranvand87@gmail.com (A.B.); amanlou@znu.ac.ir (H.A.)

2 Department of Animal Science, School of Agriculture, Shiraz University, Shiraz 71441-65186, Iran; abdollahii.arman@gmail.com

3 Department of Animal Nutrition, West Bengal University of Animal and Fishery Sciences, Belgachia, Kolkata 700037, India; patra_amlan@yahoo.com

4 Institute of Veterinary Physiology, Freie Universität Berlin, 14163 Berlin, Germany

* Correspondence: alamoutih@znu.ac.ir (H.M.-A.); joerg.aschenbach@fu-berlin.de (J.R.A.); Tel.: +98-2433052645 (H.M.-A.)

\begin{abstract}
This study was conducted to investigate the effect of decreasing concentrations of dietary neutral detergent fiber (NDF) at high rumen undegradable protein (RUP) on performance, digestibility, chewing activity, blood attributes, and carcass characteristics in 32 weaned male Afshari lambs (90 days of age; $26 \mathrm{~kg}$ initial body weight; BW). Dietary metabolic energy (ME) was increased from 10.6-11.5 and $11.8 \mathrm{MJ} / \mathrm{kg}$ dry matter (DM) by replacing alfalfa hay with grain to achieve NDF concentrations of 270, 245, and $220 \mathrm{~g} / \mathrm{kg}$ DM, respectively, at $66.6 \mathrm{~g} / \mathrm{kg}$ DM of RUP. The control (CON) diet contained 10.9 MJ/kg ME, $270 \mathrm{~g} / \mathrm{kg}$ NDF and $59.6 \mathrm{~g} / \mathrm{kg}$ RUP on DM basis. Rations containedsimilar concentrations of crude protein (CP, $160 \mathrm{~g} / \mathrm{kg}$ DM). Lambs were slaughtered after a 56-d feeding period. The increase in dietary RUP had no effect on BW and average daily gain (ADG) but tended to decrease apparent digestibility of CP and DM, significantlydecreasedplasma urea concentration, and increased carcass CP content. Other body or carcass characteristics were unchanged. Decreasing dietary fiber at high RUP did not result in adverse effects on BW, ADG, body length, withers height, apparent digestibility of DM and CP, and BFT, but decreased DM intake (1539 vs. $1706 \mathrm{~g} / \mathrm{d}$ ) and feed conversion ratio (FCR; 4.33 vs. 5.39) compared with CON. Gradual reduction in NDF and physically effective NDF did not affecteating, ruminating or chewing times. Plasma glucose concentration was greater for NDF220 than for the three other treatments $(p=0.015)$.Slaughtering traits were not affected by dietary treatment except for hot carcass weight, which increased in NDF220 and NDF245 compared with NDF270 ( $p=0.021)$. The concentration of meat CP increased in NDF270 versus CON (167 vs. $152 \mathrm{~g} / \mathrm{kg}$ ). Quadratic effects occurred for meat ether extract concentration (highest in NDF220) and fat-tail weight (highest in NDF245). In conclusion, the results showed that increasing the proportion of RUP within dietary CP improves carcass protein accretion. Decreasing dietary NDF to $220 \mathrm{~g} / \mathrm{kg}$ DM at high RUP does not impair eating behavior and improves FCR in 3-month-old fat-tailed lambs.
\end{abstract}

Keywords: dietary fiber; dietary protein; eating behavior; carcass; lamb

\section{Introduction}

Finishing lambs are important meat-producing animals in many regions of the world, providing a major source of protein. Especially in Iran, lamb meat consumption is high in comparison to the meat of other ruminants. Lamb rearing is predominantly dependent 
on pasture, which is not always sufficient for optimal live weight gain due to the limited availability of nutrients from natural grassland, especially if pasture quality is low. Growth can be accelerated and optimized by changing the proportion of forage to concentrate in indoor systems [1].

There is ample research literature on energy and protein requirements, and some modern feeding models for sheep have been published or updated in the last decade [2-4]. Still, none of the existing feeding standards or models reports optimal dietary fiber (NDF) concentrations for sheep. Therefore, it is difficult to translate energy requirements into a practical formulation of diets, considering that rumen function and microbial efficiency are markedly affected by fiber nutrients. This is a major limitation, especially for weaned lambs considering their incomplete rumen development, just emerging adaptation to solid feeds, and immature rumination behavior. Fiber-rich diets may thus profoundly impact DMI and rumen function of weaned lambs with consequences for energy and protein accretion and, finally, growth. On the other hand, excess starch fermented in the rumen might cause suboptimal rumen $\mathrm{pH}$ and associated nutritional disorders [5-7].

The Cornell Net Carbohydrate and Protein System (CNCPS) for sheep [4], as well as the Small Ruminant Nutrition System (SRNS) for sheep and goats based on CNCPS [8], suggest an optimum dietary NDF concentration of 200-245 g/kg DM. Although small ruminants adapt their feeding behavior to the fiber proportion of the offered diet $[7,9]$, a reduction in fiber concentration below $20 \%$ has been shown to increase the risk of ruminal acidosis in feedlot cattle, which can challenge animal health and welfare [10]. On the other hand, diets with excessive fiber from roughage have low net energy content, decrease feed consumption with subsequent decreases in growth rate and feed conversion efficiency, and increase the number of days to market in feedlot cattle [11,12]. Hence, most large feedlots diminish the use of roughage in finishing diets. As mentioned above, the energy restrictions and feed intake limitations could be even more pronounced in weaned lambs with developing ruminal function and high growth rate in an accelerated growth system. Increasing dietary starch inclusion may also decrease dry matter intake, initially through poor digestibility of NDF and physical NDF filling and later through chemical satiety depending on dietary and animal variables [13]. Given the nutritional models have been evaluated based on meta-analyses of microbial protein flow [2,4]. Not accounting for depressed efficiency of microbial protein synthesis with higher starch diets or reduced DMI could overpredict microbial protein supply, limiting metabolizable protein. If microbial protein supply is limited, the ration should be included with the RUP sources [14]. It has been reported that fiber resources could be used more efficiently when increasing the concentration of RUP [15]. It was likewise suggested that ruminal breakdown of excessive crude protein (CP) in alfalfa diets of dairy cows leads to inefficient $\mathrm{N}$ use and decreased milk yield [16]. In contrast, the inclusion of dietary fish meal as a RUP source to alfalfa silage-based diets increases production performance [17].

Although it is common practice to formulate nutrient composition of diets along with the concentration of NDF based on NRC [3] or CNCPS-S recommendations in intensive lamb fattening systems, the desirable level of NDF for growing-finishing lambs with accelerated growth immediately after weaning has not been determined. It is known that the responses of lambs to dietary NDF depend on the type, amount, and quality of the used fiber sources, considering that fiber quality affects rumen fill and that sheep have a higher ruminal passage rate than cattle and can ruminate very fine particles that would escape rumination in cattle [2]. Few previous studies investigated the effects of various amounts of dietary NDF on the performance of finishing lambs [18-21]. Still, no studies investigated different levels of NDF in diets containing a high concentration of RUP on productivity and feeding behavior of weaned lambs in an accelerated growth system. Our hypothesis was (1) that inclusion of high RUP would improve growth rate at high dietary NDF concentration and (2) that reducing dietary NDF levels at high RUP may potentially elicit further improvements of DMI, daily gain, the efficiency of nutrient use, carcass 
characteristics and eating behavior in growing-finishing weaned lambs in an accelerated growth system.

\section{Materials and Methods}

\subsection{Experimental Design, Animal Management, and Diets}

The Animal Care and Welfare Committee (ID 1353) at the University of Zanjan, Iran, approved this study's experimental and management protocols. Thirty-two apparently healthy Afshari male lambs, with initial body weight (BW) of $26.0 \pm 3.0 \mathrm{~kg}$ and $90.0 \pm 7.0$ days of age, were randomly assigned in a completely randomized design to four dietary treatments (8 lambs per treatment). Lambs were kept individually in separate pens $(171 \times 83 \mathrm{~cm})$ with a concrete floor equipped with water and feed bunks. The average low and high temperatures were 10 and $25^{\circ} \mathrm{C}$, respectively. The average relative humidity was in a range of $46 \%$. Lambs were adapted to diets for 21 days, followed by 56 days of an experimental feeding period. Dietary treatments were NDF270, NDF245, and NDF220 with dietary NDF concentrations of 270, 245, and $220 \mathrm{~g} / \mathrm{kg}$ dry matter (DM), respectively, at a high RUP concentration of $66.6 \mathrm{~g} / \mathrm{kg}$ DM $(415 \mathrm{~g} / \mathrm{kg} \mathrm{CP})$. Decreasing NDF concentrations were achieved by decreasing the forage to concentrate ratio from 300-100 g/ $\mathrm{kg} \mathrm{DM}$. Concentrations of ME increased with decreasing dietary NDF concentrations. High RUP concentrations were achieved by supplementing fish meal. The concentration of RUP was derived from the results of our previous studies that used RUP levels between $50-70 \mathrm{~g} / \mathrm{kg}$ feed DM in fat-tailed lambs [1,22,23]. A control (CON) diet contained $270 \mathrm{~g} / \mathrm{kg}$ DM of $\mathrm{NDF}$ and $59.6 \mathrm{~g} / \mathrm{kg}$ DM of RUP $(370 \mathrm{~g} / \mathrm{kg} \mathrm{CP})$. Rations were formulated using the CNCPS $\mathrm{S}$ software (version 1.0.21; Cornell University, Ithaka, NY, USA) to contain similar crude protein $(\mathrm{CP})$ concentrations $(160 \mathrm{~g} / \mathrm{kg} \mathrm{DM})$. The ingredients and nutrient composition of experimental diets are shown in Table 1 . The concentrate portions of experimental diets were mixed every $2 \mathrm{wk}$. To decrease variability of forage, chopped alfalfa was always derived from the same batch. Diets were totally hand-mixed for each lamb and offered in equal proportions twice daily at 0900 and $1600 \mathrm{~h}$. Feed was offered based on the previous day's intake plus an additional $50 \mathrm{~g} / \mathrm{kg}$ of total intake. Sheep were restricted to the offered feeds of $105 \%$ of the expected intake to reduce the selection of feed components. Individual pens were cleaned daily. The lambs always had free access to clean drinking water.

\subsection{Performance}

Feed offered and refusals were weighed using digital scale (MAHAK, model 14,000 plus, capacity $70 \mathrm{~kg}$ and precision $5 \mathrm{gr}$, Tehran, Iran) daily before each animal's morning feeding, and DMI was calculated. Lambs were fasted for $15 \mathrm{~h}$ before weighing. Initial and final BW were the average of two BW measurements before feeding on consecutive days, and subsequent weights were measured every 14 days during the experiment. Recordings of BW on day 0 (post-adaptation), 14, 28, 42, and 56 of the trial were finally used to calculate individual average daily gains (ADG). Simultaneously with BW recordings, body dimensions were also measured. Feed conversion ratio (FCR) was calculated as total DMI divided by total BW gain throughout the experiment.

\subsection{Eating Behavior}

Eating behavior (eating and ruminating) and resting were monitored visually every $5 \mathrm{~min}$ for a 24 -h period on day 52 of the experiment. To evaluate time spent eating or ruminating per kilogram of DM and NDF intakes, the average intake during the 24-h period of observations was used. Additionally, chewing activities were calculated as total hours for the 24-h period and based on DM and NDF intakes by dividing minutes of eating or ruminating by intake. Total chewing time was expressed as the sum of eating and ruminating time. 
Table 1. Ingredients and chemical composition of experimental diets (DM basis).

\begin{tabular}{|c|c|c|c|c|}
\hline \multirow{3}{*}{ Item } & \multicolumn{4}{|c|}{ Diets $^{\dagger}$} \\
\hline & \multirow{2}{*}{$\begin{array}{c}\text { Low RUP } \\
\text { CON }\end{array}$} & \multicolumn{3}{|c|}{ High RUP } \\
\hline & & NDF270 & NDF245 & NDF220 \\
\hline \multicolumn{5}{|l|}{ Ingredient composition, $\mathrm{g} / \mathrm{kg}$} \\
\hline Alfalfa hay & 300 & 300 & 200 & 100 \\
\hline Ground barley grain & 250 & 250 & 310 & 350 \\
\hline Ground corn grain & 250 & 250 & 260 & 290 \\
\hline Soybean meal & 110 & 65 & 80 & 94 \\
\hline Beet pulp & 50 & 65 & 80 & 95 \\
\hline Fish meal & 10 & 40 & 40 & 41 \\
\hline Sodium bicarbonate & 10 & 10 & 10 & 10 \\
\hline Calcium carbonate & 10 & 10 & 10 & 10 \\
\hline Sodium chloride salt & 5 & 5 & 5 & 5 \\
\hline Mineral and vitamin premix $\S$ & 5 & 5 & 5 & 5 \\
\hline \multicolumn{5}{|l|}{ Chemical composition $\#$} \\
\hline $\mathrm{DM}(\mathrm{g} / \mathrm{kg})$ & 860 & 860 & 860 & 860 \\
\hline $\mathrm{CP}(\mathrm{g} / \mathrm{kg} \mathrm{DM})$ & 161 & 159 & 160 & 160 \\
\hline RUP (g/kg CP) & 370 & 418 & 416 & 415 \\
\hline NDF (g/kg DM) & 272 & 272 & 243 & 221 \\
\hline $\mathrm{NFC}(\mathrm{g} / \mathrm{kg} \mathrm{DM})^{+}$ & 480 & 480 & 500 & 530 \\
\hline $\mathrm{peNDF}_{>8.0}(\mathrm{~g} / \mathrm{kg} \mathrm{DM})^{\mathbb{I}}$ & 130 & 123 & 101 & 78 \\
\hline $\mathrm{peNDF}_{>1.18}(\mathrm{~g} / \mathrm{kg} \mathrm{DM})^{\mathbb{I}}$ & 165 & 164 & 130 & 96 \\
\hline $\mathrm{ME}(\mathrm{MJ} / \mathrm{kg} \mathrm{DM})$ & 10.9 & 10.6 & 11.5 & 11.8 \\
\hline \multicolumn{5}{|c|}{ 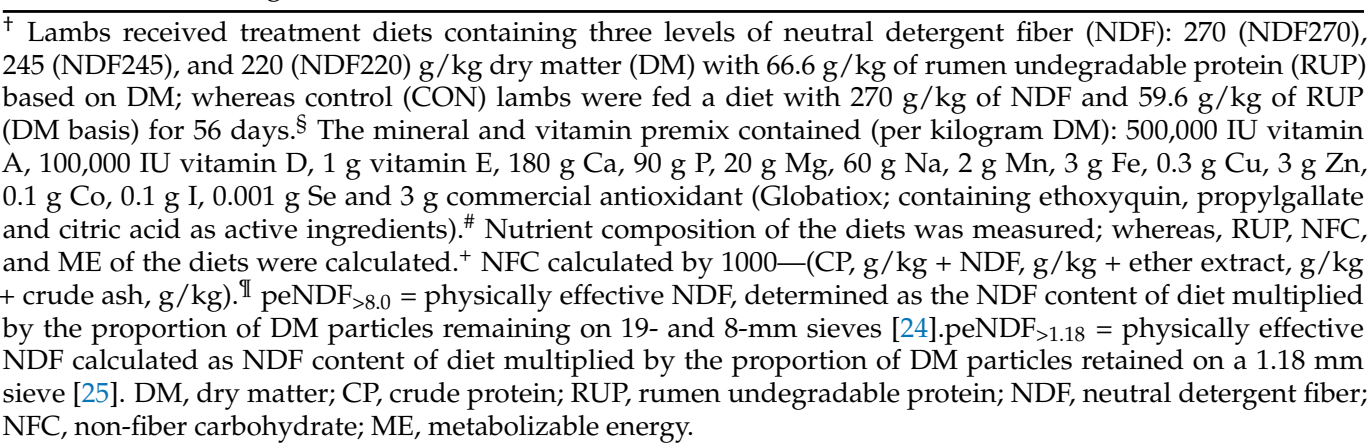 } \\
\hline
\end{tabular}

\subsection{Dry Matter and CP Digestibility}

Apparent nutrient digestibility in the total digestive tract was determined by acid insoluble ash as an internal marker. Fecal samples were collected from the rectum every $6 \mathrm{~h}$ for $48 \mathrm{~h}$ ( 4 times/d) on days 54 and 55 . The collected samples of each animal were oven-dried at $55^{\circ} \mathrm{C}$ for $24 \mathrm{~h}$, mixed together, and ground to pass through a 1-mm screen using a Wiley mill (Arthur H. Thomas Co., Philadelphia, PA, USA) for nutrient analysis. All samples were analyzed using the standard methods of AOAC [23] for DM (method 934.01), CP (method 976.05), ash (method 942.05), ether extract (EE; method 920.29), and amylase-treated NDF (aNDF) using heat-stable $\alpha$-amylase and sodium sulfite [24]. The acid insoluble ash (AIA) concentration was measured according to Van Keulen and Young [26] in feed and fecal samples as an internal marker to determine the coefficient of apparent DM and CP digestibility.

\subsection{Blood Sampling}

Onthe first and last days of the experiment, blood samples were collected in heparinized vacuum tubes from the jugular vein of each animal before offering the morning meal. Samples were immediately centrifuged $\left(3000 \times \mathrm{g}\right.$ for $20 \mathrm{~min}$ at $\left.4{ }^{\circ} \mathrm{C}\right)$ to recover plasma for storage at $-20^{\circ} \mathrm{C}$. Plasma samples were analyzed spectrophotometrically for albumin, blood urea nitrogen (BUN), glucose, calcium $(\mathrm{Ca})$, and phosphorous $(\mathrm{P})$ using 
Pars Azmoon kits (Pars Azmoon, Tehran, Iran) following the manufacturer's protocols (PerkinElmer, Colemen Instruments Division, Oak Brook, IL, USA).

\subsection{Ultrasound Measurements}

On days $0,14,28,42$, and 56 of the trial, ultrasonic measurements of the subcutaneous backfat thickness (BFT; $\mathrm{mm}$ ) and area $\left(\mathrm{cm}^{2}\right)$ of the Longissimus dorsi muscle (LDM; loin eye muscle) were performed using a portable real-time ultrasound machine (Falco100, Pie Medical Imaging, Maastricht, The Netherlands) with a multi-frequency electronic linear array probe of 5-10 MHz in B-mode. Before measurements, wool between the 12th and 13thribs area was clipped in each lamb. Animals were manually immobilized and held by two persons in the front and back of the animal. To prevent stress, ultrasound measurements were done in a half-light room far from other lambs. The transducer was covered with acoustic gel and positioned between the 12-13th ribs lateral and vertical to the vertebral column and parallel to the rib covering all the LDM. Care was taken to avoid any compression of the subcutaneous fat by the applied transducer [27]. The BFT and area of LDM were measured at the same point using high frequencies $(8-10 \mathrm{MHz})$ for superficial (BFT) and medium frequencies (7 MHz) for deeper (LDM) measurements. Ultrasound measurement data were retrieved immediately from the captured B-mode image with a digital caliper. All measurements were obtained at the left side and $4 \mathrm{~cm}$ from the vertebral column of the lambs.

\subsection{Slaughter and Carcass Quantitative Characteristics}

At the end of the feeding period, lambs in the 5.5-month age were slaughtered at the slaughterhouse of the University Farm Animal Research and Teaching Station by the HALAL procedures. Animals were weighed immediately before slaughter to obtain the slaughter body weight (SBW). After slaughtering and skinning, all the abdominal and thoracic organs and total non-carcass parts included pelt, head, heart, liver, spleen, lung, empty stomach, empty intestines, kidney, and testes were removed and weighed. The hot carcass weight $(\mathrm{HCW})$ was recorded immediately after skinning and removal of the offal parts, and the hot carcass percentage was obtained by the ratio of $(\mathrm{HCW}: \mathrm{SBW}) \times 100$. Then, carcasses were chilled at $4{ }^{\circ} \mathrm{C}$ for $24 \mathrm{~h}$ in the refrigerator and after thatreweighed to determine cold carcass weight (CCW). The dressing percentage was calculated by dividing $(\mathrm{CCW}: \mathrm{SBW}) \times 100$. The cold carcass was split longitudinally into the right and left sides. The left side of carcasses was cut into pieces, including neck, leg, shoulder, rib-flank, loinback, and fat-tail, and each part was weighed separately. After fat-tail, bone, cartilage, and the back strap were removed from the left side of the carcass, the whole soft tissue of carcass from four lambs per treatment was ground twice and mixed before samples were collected for chemical analysis. The chemical composition of representative samples was analyzed using the procedures described by AOAC [28] for CP (method 981.10), ash (method 920.153), and EE (method 960.39). Moisture content was assessed by drying $50 \mathrm{~g}$ of samples placed in aluminum dishes for $72 \mathrm{~h}$ at $60^{\circ} \mathrm{C}$.

\subsection{Statistical Analyses}

Data were tested for normality using PROC UNIVARIATE (Version 9.4; SAS Institute Inc., Cary, NC, USA). Single data including eating behavior, digestibility, blood metabolites, carcass traits, and repeated measurement data over time such as DMI, BW, ADG, body dimensions, FCR, BFT, and LDM area were analyzed using the MIXED procedure of SAS (Version 9.4; SAS Institute Inc). The statistical model for single data was: $Y_{i k}=\mu+D_{i}+$ $L_{k}\left(D_{i}\right)+e_{i k}$; where $Y_{i k}$ is the dependent variable, $\mu$ is the overall mean, $D_{i}$ is the fixed effect of dietary treatment $i, L_{k}\left(D_{i}\right)$ is the random effect of lamb nested in the dietary treatment, and $\mathrm{e}_{\mathrm{ik}}$ is the residual error. For repeated measurement data, sampling time and sampling time $\times$ treatment were added to the model. Lamb nested within treatment for each analyzed parameter was subjected to three covariance structures: compound symmetric, autoregressive order one, and unstructured covariance. A variance-covariance 
structure was chosen based on the best Akaike information criterion. Mean comparisons were performed by the least square mean (LSM) method, and differences were compared using Tukey test. To avoid any bias in variance parameters, effects of the initial body weight of lambs were added as a covariate to the model. The covariates were removed from the model one at a time, starting with the least significant in a backward stepwise manner if its significance probability was $>0.1$. Contrasts were calculated to test the differences between two protein levels (i.e., CON versus NDF270) and to determine the linear or quadratic response to the decreasing NDF content in the three treatment diets (NDF270, NDF245, and NDF220). Significance and tendency for differences between treatments were determined at $p<0.05$ and $0.05 \leq p<0.10$, respectively. Data were expressed as $\mathrm{LSM} \pm$ standard error of the mean (SEM) unless otherwise stated.

\section{Results}

\subsection{Feed Intake, Growth, and Body Dimensions}

Diet $\times$ time interaction effect was not significant (Table 2) for any feed intake, growth, and body dimensions variables. Lambs fed $220 \mathrm{~g} / \mathrm{kg}$ NDF with a high RUP had lower $(1539 \mathrm{~g} / \mathrm{d})$ overall DMI than those fed CON and NDF270 (1706 g/d for both) diets during the entire period. Among the different periods, DMI was decreased specifically in the first and second 14-day periods in the NDF220 group compared to CON and NDF270. The depressing effects of decreasing NDF on DMI were linear from NDF270 towards NDF220 for the whole experiment and for the first and second 14-d period of the trial. Although NDF220 diet decreased ADG in the first 14 days of the trial compared to NDF245, dietary treatment did not affect BW and ADG during the whole experimental period. Thus, the lower DMI observed for lambs fed with NDF220 penetrated to lower overall FCR (4.33), irrespective of the fact that lowest period FCR was observed for NDF245 in the first 14-d trial period. At the linear and quadratic effects level, decreasing NDF resulted in a tendency to have a quadratic pattern for BW in the first 14-day period (highest in NDF245) and a quadratic pattern for BW in the second 14-day period of trial (highest in NDF245). For ADG, a quadratic pattern (highest in NDF245) was observed in the first 14-day period of the trial. A tendency for a linear increase with increasing NDF existed in the last 14-day period of the trial. With decreasing NDF, FCR decreased linearly in the first, second, and fourth day-14 period of trial. When comparing CON with NDF270, an increase of RUP from $59.6-66.6 \mathrm{~g} / \mathrm{kg}$ tended to increase ADG in the third 14-day period of trial and FCR in the first and fourth 14-day period of trial.

As detailed in Table 3, no differences were observed in body length and withers height among treatments. The value of heart girth tended to be greater in lambs fed NDF245 than in those fed on the CON diet. In addition, offering NDF245 increased heart girth on day 42 and a tendency on day 56 compared with CON. Likewise, decreasing concentrations of NDF in diets led to quadratic patterns for hearth girth across periods and in the third and fourth 14-day period, with the highest values for the NDF245 group. 
Table 2. Dry matter intake (DMI), body weight (BW), average daily gains (ADG), and feed conversion ratio (FCR) in lambs fed diets with different levels of neutral detergent fiber (NDF) and rumen undegradable protein (RUP).

\begin{tabular}{|c|c|c|c|c|c|c|c|c|c|c|c|}
\hline \multirow{3}{*}{ Item } & \multirow{3}{*}{$\begin{array}{c}\text { Diet }^{\dagger} \\
\text { Low RUP } \\
\text { CON }\end{array}$} & \multirow{2}{*}{\multicolumn{3}{|c|}{$\begin{array}{c}\text { Diet }^{\text {a }} \\
\text { High RUP }\end{array}$}} & \multirow{3}{*}{ SEM § } & \multicolumn{3}{|c|}{$p$-Value ${ }^{+}$} & \multicolumn{3}{|c|}{$p$-Value } \\
\hline & & & & & & \multirow{2}{*}{ D } & \multirow{2}{*}{$\mathbf{L}$} & \multirow{2}{*}{$\mathbf{Q}$} & \multirow{2}{*}{$\begin{array}{l}\text { CON vs. } \\
\text { NDF270 }\end{array}$} & \multirow{2}{*}{$\mathbf{T}$} & \multirow{2}{*}{$\mathbf{D} \times \mathbf{T}$} \\
\hline & & NDF270 & NDF245 & NDF220 & & & & & & & \\
\hline DMI $(g / d)$ & $1706^{a}$ & $1706^{a}$ & $1639^{a b}$ & $1539^{b}$ & 42.1 & 0.028 & 0.007 & 0.73 & 0.99 & $<0.001$ & 0.15 \\
\hline $1-14 \mathrm{~d}$ & $1508^{a}$ & $1496^{\mathrm{a}}$ & $1364^{\mathrm{a}}$ & $1202^{b}$ & 57.9 & $<0.001$ & $<0.001$ & 0.77 & 0.84 & & \\
\hline $15-28 \mathrm{~d}$ & $1742^{\mathrm{a}}$ & $1715^{\mathrm{a}}$ & $1673^{\mathrm{ab}}$ & $1535^{b}$ & 63.3 & 0.014 & 0.009 & 0.38 & 0.67 & & \\
\hline $29-42 \mathrm{~d}$ & 1749 & 1813 & 1756 & 1692 & 92.1 & 0.63 & 0.15 & 0.96 & 0.48 & & \\
\hline $43-56 \mathrm{~d}$ & 1819 & 1793 & 1769 & 1731 & 96.4 & 0.82 & 0.51 & 0.93 & 0.79 & & \\
\hline Initial BW (kg) & 25.4 & 26.6 & 26.1 & 26.7 & 0.88 & 0.45 & 0.88 & 0.44 & 0.18 & & \\
\hline $\begin{array}{l}\text { BW on the last day } \\
\text { of adaptation }(\mathrm{kg})\end{array}$ & 32.5 & 32.9 & 32.6 & 32.2 & 0.59 & 0.73 & 0.30 & 0.84 & 0.56 & & \\
\hline $\mathrm{BW}(\mathrm{kg})$ & 40.8 & 40.6 & 41.6 & 40.4 & 0.55 & 0.41 & 0.86 & 0.104 & 0.68 & $<0.001$ & 0.52 \\
\hline d 14 & 39.8 & 39.5 & 40.4 & 38.4 & 0.86 & 0.15 & 0.19 & 0.059 & 0.75 & & \\
\hline d 28 & 44.6 & 43.9 & 45.4 & 43.5 & 0.81 & 0.13 & 0.57 & 0.037 & 0.41 & & \\
\hline $\mathrm{d} 42$ & 48.8 & 48.7 & 50.1 & 48.7 & 0.99 & 0.43 & 0.93 & 0.100 & 0.98 & & \\
\hline d 56 & 55.2 & 53.4 & 56.7 & 55.4 & 1.29 & 0.38 & 0.46 & 0.13 & 0.57 & & \\
\hline $\operatorname{ADG}(\mathrm{g} / \mathrm{d})$ & 355 & 348 & 376 & 354 & 11.7 & 0.36 & 0.74 & 0.085 & 0.71 & $<0.001$ & 0.32 \\
\hline $1-14 \mathrm{~d}$ & $534^{a b}$ & $463^{a b}$ & $555^{a}$ & $429^{b}$ & 42.5 & 0.019 & 0.42 & 0.010 & 0.103 & & \\
\hline $15-28 \mathrm{~d}$ & 348 & 319 & 355 & 364 & 39.3 & 0.69 & 0.24 & 0.68 & 0.47 & & \\
\hline $29-42 \mathrm{~d}$ & 295 & 372 & 336 & 340 & 42.2 & 0.36 & 0.41 & 0.55 & 0.071 & & \\
\hline $43-56 \mathrm{~d}$ & 315 & 264 & 329 & 339 & 38.3 & 0.23 & 0.086 & 0.45 & 0.19 & & \\
\hline FCR II & $5.39^{a b}$ & $5.49^{\mathrm{a}}$ & $4.66^{b c}$ & $4.33^{c}$ & 0.26 & 0.011 & 0.001 & 0.36 & 0.78 & $<0.001$ & 0.30 \\
\hline $1-14 \mathrm{~d}$ & $3.00^{\mathrm{ab}}$ & $3.27^{\mathrm{a}}$ & $2.53^{b}$ & $2.78^{a b}$ & 0.23 & 0.027 & 0.034 & 0.007 & 0.084 & & \\
\hline $15-28 d$ & 5.31 & 5.59 & 5.01 & 4.39 & 0.62 & 0.14 & 0.031 & 0.85 & 0.95 & & \\
\hline $29-42 \mathrm{~d}$ & 7.30 & 5.40 & 5.41 & 4.82 & 1.07 & 0.13 & 0.21 & 0.48 & 0.12 & & \\
\hline $42-56 \mathrm{~d}$ & 5.95 & 7.72 & 5.68 & 5.32 & 0.93 & 0.072 & 0.028 & 0.39 & 0.081 & & \\
\hline
\end{tabular}

${ }^{\dagger}$ Lambs received treatment diets with three levels of NDF: 270 (NDF270), 245 (NDF245), and 220 (NDF220) g/kg dry matter (DM) with $66.6 \mathrm{~g} / \mathrm{kg}$ of RUP based on DM; whereas control (CON) lambs were fed a diet with NDF at $270 \mathrm{~g} / \mathrm{kg}$ DM and RUP at $59.6 \mathrm{~g} / \mathrm{kg}$ DM for 56 days. \$ SEM, standard error of the means. ${ }^{+}$Least square means within a row with different superscripts $(\mathrm{a}-\mathrm{c})$ differ $(p<0.05) .{ }^{\mathbb{I I}} \mathrm{FCR}$ was calculated as DMI divided by BW gain. Linear (L) and quadratic (Q) effects for the three treatments diets (NDF270, NDF245, and NDF220); D, diet; $T$, time.

Table 3. Body dimensions in lambs receiving diets with various levels of neutral detergent fiber (NDF) and rumen undegradable protein (RUP).

\begin{tabular}{|c|c|c|c|c|c|c|c|c|c|c|c|}
\hline \multirow{3}{*}{ Item } & \multicolumn{4}{|c|}{ Diet $^{+}$} & \multirow{3}{*}{ SEM $^{\S}$} & \multicolumn{6}{|c|}{$p$-Value ${ }^{+}$} \\
\hline & \multirow{2}{*}{$\frac{\text { Low RUP }}{\text { CON }}$} & \multicolumn{3}{|c|}{ High RUP } & & \multirow{2}{*}{ D } & \multirow{2}{*}{$\mathbf{L}$} & \multirow{2}{*}{$\mathbf{Q}$} & \multirow{2}{*}{$\begin{array}{l}\text { CON vs. } \\
\text { NDF270 }\end{array}$} & \multirow{2}{*}{$\mathbf{T}$} & \multirow{2}{*}{$\mathbf{D} \times \mathbf{T}$} \\
\hline & & NDF270 & NDF245 & NDF220 & & & & & & & \\
\hline Body length (cm) & 41.0 & 41.1 & 40.4 & 40.7 & 0.49 & 0.76 & 0.60 & 0.50 & 0.92 & $<0.001$ & 0.56 \\
\hline d 14 & 40.6 & 40.0 & 39.6 & 39.7 & 0.72 & 0.53 & 0.74 & 0.71 & 0.39 & & \\
\hline d 28 & 40.1 & 40.1 & 39.7 & 39.8 & 0.53 & 0.83 & 0.64 & 0.60 & 1.00 & & \\
\hline $\mathrm{d} 42$ & 40.8 & 41.0 & 40.2 & 40.6 & 0.70 & 0.70 & 0.58 & 0.36 & 0.86 & & \\
\hline d 56 & 42.6 & 43.3 & 42.2 & 42.6 & 0.72 & 0.47 & 0.35 & 0.28 & 0.31 & & \\
\hline Withers height $(\mathrm{cm})$ & 68.9 & 68.8 & 68.4 & 70.0 & 0.62 & 0.31 & 0.24 & 0.26 & 0.91 & $<0.001$ & 0.39 \\
\hline $\mathrm{d} 14$ & 65.0 & 64.1 & 64.4 & 65.1 & 0.66 & 0.43 & 0.17 & 0.78 & 0.21 & & \\
\hline d 28 & 67.3 & 67.6 & 66.8 & 68.5 & 0.79 & 0.24 & 0.34 & 0.14 & 0.75 & & \\
\hline $\mathrm{d} 42$ & 70.7 & 70.7 & 70.2 & 72.3 & 1.00 & 0.19 & 0.17 & 0.20 & 1.00 & & \\
\hline d 56 & 73.0 & 73.0 & 72.2 & 74.3 & 0.98 & 0.19 & 0.23 & 0.15 & 0.80 & & \\
\hline Heart girth $(\mathrm{cm})$ & 77.9 & 78.3 & 80.1 & 78.7 & 0.57 & 0.055 & 0.64 & 0.048 & 0.69 & $<0.001$ & 0.14 \\
\hline d 14 & 68.2 & 69.3 & 69.6 & 69.0 & 0.90 & 0.46 & 0.68 & 0.58 & 0.22 & & \\
\hline d 28 & 75.0 & 75.6 & 76.3 & 75.7 & 1.02 & 0.64 & 0.94 & 0.51 & 0.54 & & \\
\hline $\mathrm{d} 42$ & $82.2^{b}$ & $82.1^{\mathrm{b}}$ & $85.4^{\mathrm{a}}$ & $83.0^{\mathrm{b}}$ & 0.86 & 0.002 & 0.35 & 0.003 & 0.88 & & \\
\hline d 56 & 86.1 & 86.1 & 89.3 & 87.2 & 1.28 & 0.056 & 0.44 & 0.042 & 1.00 & & \\
\hline
\end{tabular}

${ }^{\dagger}$ Lambs received treatment diets containing three levels of NDF: 270 (NDF270), 245 (NDF245), and 220 (NDF220) g/kg dry matter (DM) with $66.6 \mathrm{~g} / \mathrm{kg}$ of RUP based on DM; whereas control (CON) lambs were fed a diet containing $270 \mathrm{~g} / \mathrm{kg}$ of NDF and $59.6 \mathrm{~g} / \mathrm{kg}$ of RUP (DM basis) for 56 days. ${ }^{\S}$ SEM, standard error of the means. ${ }^{+}$Least square means within a row with different superscripts $(\mathrm{a}, \mathrm{b})$ differ $(p<0.05)$ Linear (L) and quadratic (Q) effects for the three treatments diets (NDF270, NDF245, and NDF220); D, diet; T, time. 


\subsection{Digestibility and Eating Behavior}

Offering NDF220 decreased DM digestibility () compared with NDF245. When comparing CON and NDF270 treatments, the increase of RUP from $59.6-66.6 \mathrm{~g} / \mathrm{kg}$ tended to decrease the apparent digestibility of both $\mathrm{DM}$ and $\mathrm{CP}$. Coherent with these findings, the digestibility of DM changed quadratically with the greatest digestibility for the NDF245 group (Table 4).

No treatment differences were observed in resting time and total times of eating, ruminating, and chewing (Table 4), although the increase of RUP from $59.6 \mathrm{~g} / \mathrm{kg}$ to $66.6 \mathrm{~g} / \mathrm{kg}$ decreased the total time of ruminating ( $\mathrm{min} / \mathrm{d}$ ) when comparing CON with NDF270 individually. Time of eating, ruminating, and chewing expressed as minutes per kilogram of NDF intake was longer for the NDF220 diet than the CON and NDF270 diets. Still, there were no differences when expressed as minutes per kilogram of DMI among dietary treatments. Furthermore, decreasing NDF concentrations led to linear increases in eating, ruminating and chewing times per kilogram of NDF intake and ruminating and chewing times per kilogram of DMI.

Table 4. Effects of feeding various levels of neutral detergent fiber (NDF) and rumen undegradable protein (RUP) on apparent nutrient digestibility and eating patterns of fat-tailed lambs.

\begin{tabular}{|c|c|c|c|c|c|c|c|c|c|}
\hline \multirow{3}{*}{ Item } & \multicolumn{4}{|c|}{$\operatorname{Diet}^{+}$} & \multirow{3}{*}{ SEM $^{\S}$} & \multicolumn{4}{|c|}{$p$-Value ${ }^{+}$} \\
\hline & \multirow{2}{*}{$\frac{\text { Low RUP }}{\text { CON }}$} & \multicolumn{3}{|c|}{ High RUP } & & \multirow{2}{*}{$\mathbf{D}$} & \multirow{2}{*}{$\mathbf{L}$} & \multirow{2}{*}{$\mathbf{Q}$} & \multirow{2}{*}{$\begin{array}{l}\text { CON vs. } \\
\text { NDF270 }\end{array}$} \\
\hline & & NDF270 & NDF245 & NDF220 & & & & & \\
\hline \multicolumn{10}{|c|}{ Apparent digestibility $(\mathrm{g} / \mathrm{kg})$} \\
\hline Dry matter & $645^{\mathrm{ab}}$ & $619^{a b}$ & $659^{a}$ & $606^{\mathrm{b}}$ & 13.2 & 0.012 & 0.36 & 0.007 & 0.083 \\
\hline Crude protein & 720 & 622 & 697 & 630 & 46.3 & 0.14 & 0.88 & 0.12 & 0.059 \\
\hline \multicolumn{10}{|l|}{ Eating } \\
\hline Total time $(\mathrm{min} / \mathrm{d})$ & 258 & 263 & 262 & 257 & 14.7 & 0.96 & 0.69 & 0.89 & 0.73 \\
\hline $\min / \mathrm{kg}$ DMI & 15.3 & 15.5 & 16.0 & 16.8 & 1.05 & 0.51 & 0.23 & 0.83 & 0.82 \\
\hline $\mathrm{min} / \mathrm{kg} \mathrm{NDF}$ intake & $28.4^{\mathrm{b}}$ & $28.8^{\mathrm{b}}$ & $32.9^{a b}$ & $38.2^{\mathrm{a}}$ & 2.05 & $<0.001$ & $<0.001$ & 0.73 & 0.83 \\
\hline \multicolumn{10}{|l|}{ Ruminating } \\
\hline Total time $(\mathrm{min} / \mathrm{d})$ & 447 & 413 & 440 & 416 & 16.1 & 0.11 & 0.88 & 0.102 & 0.045 \\
\hline $\min / \mathrm{kg}$ DMI & 26.4 & 24.5 & 26.8 & 27.3 & 1.38 & 0.20 & 0.049 & 0.44 & 0.17 \\
\hline $\mathrm{min} / \mathrm{kg}$ NDF intake & $48.9^{b c}$ & $45.3^{c}$ & $55.3^{\mathrm{ab}}$ & $62.1^{\mathrm{a}}$ & 2.81 & $<0.001$ & $<0.001$ & 0.55 & 0.21 \\
\hline \multicolumn{10}{|l|}{ Chewing } \\
\hline Total time $(\mathrm{min} / \mathrm{d})$ & 705 & 671 & 708 & 680 & 23.5 & 0.31 & 0.71 & 0.14 & 0.19 \\
\hline $\min / \mathrm{kg}$ DMI & 41.6 & 39.7 & 43.3 & 44.6 & 2.19 & 0.16 & 0.049 & 0.58 & 0.39 \\
\hline $\mathrm{min} / \mathrm{kg}$ NDF intake & $77.1^{\mathrm{c}}$ & $73.5^{c}$ & $89.1^{\mathrm{b}}$ & $101.3^{\mathrm{a}}$ & 4.39 & $<0.001$ & $<0.001$ & 0.69 & 0.42 \\
\hline Resting time $(\mathrm{min} / \mathrm{d})$ & 467 & 511 & 462 & 496 & 37.6 & 0.52 & 0.71 & 0.25 & 0.25 \\
\hline
\end{tabular}

\subsection{Blood Variables, Longissimus Dorsi Muscle Area and Backfat Thickness}

Concentrations of plasma albumin, $\mathrm{Ca}$ and $\mathrm{P}$ were not different among treatments (Table 5). Still, plasma BUN concentration was decreased by feeding different levels of NDF at high RUP compared with CON. Coherently, lambs fed NDF270 had lower plasma BUN concentrations than $\mathrm{CON}$ in the individual comparison between CON vs. NDF270. Lambs fed NDF220 showed higher plasma glucose levelsthan three other treatments, supported by a linear increase in plasma glucose concentration with decreasing NDF concentrations.

Individual comparisons of BFT between CON vs. NDF270 tended to show increased values in NDF270 across periods (Table 6), which was based on significantly higher values on trial days 42 and 56 . Coherently, decreasing concentrations of NDF tended to be coupled to linear decreases of BFT on trial day 56. Overall differences in LDM area did also not reach statistical significance. In contrast to BFT, however, direct comparisons between $\mathrm{CON}$ vs. NDF270 showed a trend for an overall decrease across periods, primarily based on lower LDM area on trial days 42 and 56. 
Table 5. Effects of feeding different levels of neutral detergent fiber (NDF) and rumen undegradable protein (RUP) on blood plasma attributes of finishing lambs.

\begin{tabular}{|c|c|c|c|c|c|c|c|c|c|}
\hline \multirow{3}{*}{ Item } & \multicolumn{4}{|c|}{$\operatorname{Diet}^{+}$} & \multirow{3}{*}{ SEM $^{\S}$} & \multicolumn{4}{|c|}{$p$-Value ${ }^{+}$} \\
\hline & \multirow{2}{*}{$\frac{\text { Low RUP }}{\text { CON }}$} & \multicolumn{3}{|c|}{ High RUP } & & \multirow{2}{*}{ D } & \multirow{2}{*}{$\mathbf{L}$} & \multirow{2}{*}{$\mathbf{Q}$} & \multirow{2}{*}{$\begin{array}{l}\text { CON vs } \\
\text { NDF270 }\end{array}$} \\
\hline & & NDF270 & NDF245 & NDF220 & & & & & \\
\hline Albumin (g/L) & 46.0 & 45.1 & 49.3 & 44.6 & 1.83 & 0.82 & 0.86 & 0.42 & 0.73 \\
\hline BUN (mmol/L) & $6.61^{a}$ & $5.02^{b}$ & $5.37^{\mathrm{b}}$ & $4.93^{\mathrm{b}}$ & 0.30 & 0.002 & 0.84 & 0.29 & 0.001 \\
\hline Glucose (mmol/L) & $4.48^{\mathrm{b}}$ & $4.49^{b}$ & $4.46^{b}$ & $5.18^{a}$ & 0.17 & 0.015 & 0.010 & 0.091 & 0.95 \\
\hline $\mathrm{Ca}(\mathrm{mmol} / \mathrm{L})$ & 2.24 & 2.39 & 2.35 & 2.20 & 0.21 & 0.90 & 0.47 & 0.81 & 0.61 \\
\hline $\mathrm{P}(\mathrm{mmol} / \mathrm{L})$ & 1.64 & 1.54 & 1.62 & 1.61 & 0.18 & 0.98 & 0.79 & 0.85 & 0.69 \\
\hline
\end{tabular}

${ }^{\dagger}$ Lambs received treatment diets with three levels of NDF: (NDF270), 245 (NDF245) and 220 (NDF220) g/kg DM with 66.6 g/kg of RUP based on dry matter (DM); while whereas control (CON) lambs were fed a diet with $270 \mathrm{~g} / \mathrm{kg}$ of NDF and $59.6 \mathrm{~g} / \mathrm{kg}$ of RUP (DM basis) for 56 days. Linear (L) and quadratic (Q) effects for the three treatment diets (NDF270, NDF245, and NDF220); D, diet; BUN, blood urea nitrogen; $\mathrm{Ca}$, calcium; $\mathrm{P}$, phosphorous. ${ }^{\S} \mathrm{SEM}$, standard error of the means. ${ }^{+}$Least square means within a row with different superscripts $(\mathrm{a}, \mathrm{b})$ differ $(p<0.05)$.

Table 6. Ultrasound measurements of Longissimus dorsi muscle area and subcutaneous backfat thickness (BFT) in lambs fed different levels of dietary neutral detergent fiber (NDF) and rumen undegradable protein (RUP).

\begin{tabular}{|c|c|c|c|c|c|c|c|c|c|c|c|}
\hline \multirow{3}{*}{ Item } & \multicolumn{4}{|c|}{ Diet $^{+}$} & \multirow{3}{*}{ SEM $\$$} & \multicolumn{6}{|c|}{$p$-Value } \\
\hline & \multirow{2}{*}{$\frac{\text { Low RUP }}{\text { CON }}$} & \multicolumn{3}{|c|}{ High RUP } & & \multirow{2}{*}{ D } & \multirow{2}{*}{$\mathbf{L}$} & \multirow{2}{*}{$\mathrm{Q}$} & \multirow{2}{*}{$\begin{array}{l}\text { CON vs. } \\
\text { NDF270 }\end{array}$} & \multirow{2}{*}{$\mathbf{T}$} & \multirow{2}{*}{$\mathbf{D} \times \mathbf{T}$} \\
\hline & & NDF270 & NDF245 & NDF220 & & & & & & & \\
\hline $\mathrm{BFT}(\mathrm{mm})$ & 4.18 & 4.75 & 4.34 & 4.31 & 0.19 & 0.23 & 0.14 & 0.46 & 0.061 & $<0.001$ & 0.34 \\
\hline d 14 & 2.87 & 2.75 & 2.75 & 2.87 & 0.19 & 0.83 & 0.54 & 0.73 & 0.52 & & \\
\hline d 28 & 3.87 & 4.25 & 3.62 & 3.87 & 0.38 & 0.45 & 0.37 & 0.23 & 0.35 & & \\
\hline $\mathrm{d} 42$ & 4.50 & 5.37 & 5.00 & 4.75 & 0.38 & 0.16 & 0.13 & 0.85 & 0.032 & & \\
\hline d 56 & 5.50 & 6.37 & 6.00 & 5.75 & 0.38 & 0.16 & 0.078 & 0.65 & 0.017 & & \\
\hline $\begin{array}{l}\text { L. dorsi area } \\
\qquad\left(\mathrm{cm}^{2}\right)\end{array}$ & 23.5 & 22.2 & 22.6 & 22.7 & 0.48 & 0.39 & 0.48 & 0.80 & 0.094 & $<0.001$ & 0.093 \\
\hline d 14 & 19.0 & 18.8 & 19.1 & 18.9 & 0.60 & 0.97 & 1.00 & 0.63 & 0.83 & & \\
\hline d 28 & 21.5 & 21.5 & 21.3 & 21.7 & 0.81 & 0.97 & 0.77 & 0.74 & 1.00 & & \\
\hline $\mathrm{d} 42$ & 25.7 & 23.2 & 24.1 & 24.2 & 0.92 & 0.081 & 0.30 & 0.65 & 0.011 & & \\
\hline d 56 & 27.8 & 25.3 & 26.1 & 26.3 & 0.93 & 0.079 & 0.28 & 0.58 & 0.021 & & \\
\hline
\end{tabular}

${ }^{\dagger}$ Lambs received treatment diets containing three levels of NDF: 270 (NDF270), 245 (NDF245) and 220 (NDF220) g/kg dry matter (DM) with $66.6 \mathrm{~g} / \mathrm{kg}$ of RUP based on DM; whereas control (CON) lambs were fed a diet with $270 \mathrm{~g} / \mathrm{kg}$ of NDF and $59.6 \mathrm{~g} / \mathrm{kg}$ of RUP (DM basis) for 56 days. \$ SEM, standard error of the means. Linear (L) and quadratic (Q) effects for the three treatments diets (NDF270, NDF245, and NDF220); D, diet; T, time.

\subsection{Slaughter and Carcass Traits and Chemical Composition of Meat}

No treatment effect was observed for SBW, hot carcass percentage, cold carcass weight, cold dressing percentage, and cold carcass weight without fat-tail (Table 7). The weights of non-carcass parts $(\mathrm{kg})$ were not affected by dietary treatment. Hot carcass weight $(\mathrm{kg})$ increased in sheep fed NDF245 and NDF220 relative to those receiving NDF270. This was logically supported by a quadratic increase of hot carcass weight with increasing NDF and a linear increase in hot dressing percentage.Regarding carcass cuts, the weight of neck, shoulder, rib-flank, loin-back, and also proportions of total internal organ fat, fat-tail:cold carcass, fat-tail:hot carcass and fat-tail:SBW was not different among treatments. However, lambs in the NDF220 and NDF245 groups tended to have heavier legs than the CON group. Fat-tail weight tended to be heavier in NDF245 relative to NDF270, coupled to a trend for a quadratic increase of fat-tail weight with increasing NDF (greatest in NDF245). Total internal organ fat and proportion of fat-tail relative to cold carcass also tended to change or changed quadratically, again, with the greatest values for NDF245. Finally, sheep receiving diet NDF270 tended to have lower fat-tail weight compared with CON. 
Table 7. Effects of feeding different levels of neutral detergent fiber (NDF) and rumen undegradable protein (RUP) on slaughter and carcass quantitative traits of fat-tailed lambs.

\begin{tabular}{|c|c|c|c|c|c|c|c|c|c|}
\hline \multirow{3}{*}{ Item } & \multicolumn{4}{|c|}{$\operatorname{Diet}^{+}$} & \multirow{3}{*}{ SEM $§$} & \multicolumn{4}{|c|}{$p$-Value ${ }^{+}$} \\
\hline & \multirow{2}{*}{$\begin{array}{c}\text { Low RUP } \\
\text { CON }\end{array}$} & \multicolumn{3}{|c|}{ High RUP } & & \multirow{2}{*}{$\mathbf{D}$} & \multirow{2}{*}{$\mathbf{L}$} & \multirow{2}{*}{$\mathbf{Q}$} & \multirow{2}{*}{$\begin{array}{l}\text { CON vs } \\
\text { NDF270 }\end{array}$} \\
\hline & & NDF270 & NDF245 & NDF220 & & & & & \\
\hline \multicolumn{10}{|l|}{ Slaughtering data } \\
\hline SBW $(\mathrm{kg})$ & 54.3 & 53.9 & 56.1 & 55.8 & 1.72 & 0.56 & 0.24 & 0.34 & 0.79 \\
\hline Hot carcass weight $(\mathrm{kg})$ & $26.5^{\mathrm{ab}}$ & $26.0^{\mathrm{b}}$ & $27.9^{\mathrm{a}}$ & $27.7^{\mathrm{a}}$ & 0.54 & 0.021 & 0.007 & 0.019 & 0.37 \\
\hline Hot dressing percentage (\%) & 49.6 & 48.9 & 49.3 & 50.5 & 0.63 & 0.14 & 0.031 & 0.56 & 0.30 \\
\hline Cold carcass weight $(\mathrm{k}) \mathrm{g}$ & 25.9 & 25.5 & 25.1 & 25.4 & 0.81 & 0.81 & 0.92 & 0.66 & 0.61 \\
\hline Cold dressing percentage (\%) & 47.5 & 47.3 & 45.1 & 45.7 & 1.48 & 0.36 & 0.19 & 0.24 & 0.90 \\
\hline Cold carcass with no fat-tail (kg) & 20.1 & 20.0 & 19.1 & 19.8 & 0.82 & 0.66 & 0.80 & 0.33 & 0.96 \\
\hline Total non-carcass parts $(\mathrm{kg})$ II & 13.8 & 14.0 & 14.1 & 13.5 & 0.57 & 0.75 & 0.44 & 0.54 & 0.71 \\
\hline \multicolumn{10}{|l|}{ Carcass cuts (kg) } \\
\hline Neck & 1.62 & 1.71 & 1.88 & 1.90 & 0.28 & 0.73 & 0.58 & 0.78 & 0.76 \\
\hline Shoulder & 3.93 & 3.93 & 3.92 & 4.12 & 0.195 & 0.70 & 0.41 & 0.58 & 1.00 \\
\hline Rib-flank & 3.75 & 3.78 & 3.74 & 3.91 & 0.10 & 0.37 & 0.13 & 0.53 & 0.81 \\
\hline Loin-back & 3.83 & 3.73 & 3.86 & 4.03 & 0.272 & 0.74 & 0.30 & 0.91 & 0.72 \\
\hline Leg & 5.01 & 5.26 & 5.52 & 5.48 & 1.83 & 0.080 & 0.27 & 0.12 & 0.19 \\
\hline Fat-tail & 5.85 & 5.47 & 6.00 & 5.61 & 0.18 & 0.071 & 0.28 & 0.006 & 0.067 \\
\hline Total internal organ fat $\#$ & 0.90 & 1.04 & 1.17 & 0.93 & 0.11 & 0.13 & 0.25 & 0.095 & 0.23 \\
\hline Fat-tail/cold carcass $(\%)$ & 22.3 & 21.5 & 23.8 & 22.0 & 1.07 & 0.23 & 0.57 & 0.039 & 0.46 \\
\hline Fat-tail/SBW (\%) & 10.7 & 10.1 & 10.8 & 10.0 & 0.52 & 0.37 & 0.47 & 0.19 & 0.11 \\
\hline
\end{tabular}

${ }^{+}$Lambs received diets with three levels of NDF: 270 (NDF270), 245 (NDF245), and 220 (NDF220) g/kg DM with 66.6 g/kg of RUP based on dry matter (DM); whereas control (CON) lambs were fed $270 \mathrm{~g} / \mathrm{kg}$ of NDF and $59.6 \mathrm{~g} / \mathrm{kg}$ of RUP (DM basis) for 56 days. § SEM, standard

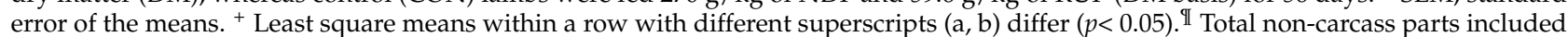
pelt, head, heart, liver, spleen, lung, empty stomach, empty intestines, kidney, and testes. "Weight of total internal organ fat divided by slaughter body weight. Linear (L) and quadratic $(\mathrm{Q})$ effects for the three treatments diets (NDF270, NDF245, and NDF220); SBW, slaughter body weight; $\mathrm{D}$, diet.

Deboned carcasses of sheep receiving the NDF270 diet had higher crude protein concentration (167 vs. $152 \mathrm{~g} / \mathrm{kg}$ ) and tended to have higher ash concentration compared to the NDF220 diet (Table 8). This was coupled to linear decreases of crude protein and ash concentrations by feeding decreasing levels of NDF. Crude protein concentration of treatments NDF270 and NDF245 was additionally higher than that of sheep receiving CON. There was no difference among treatments for ether extract concentration. However, ether extract linearly and quadratically increased by feeding decreasing levels of NDF.

Table 8. Chemical composition ( $\mathrm{g} / \mathrm{kg}$ as is) of deboned carcasses of finishing lambs fed different levels of dietary neutral detergent fiber (NDF) and high rumen undegradable protein (RUP).

\begin{tabular}{|c|c|c|c|c|c|c|c|c|c|}
\hline \multirow{3}{*}{ Item } & \multicolumn{4}{|c|}{$\operatorname{Diet}^{\dagger}$} & \multirow{3}{*}{ SEM $^{\S}$} & \multicolumn{4}{|c|}{$p$-Value $^{+}$} \\
\hline & \multirow{2}{*}{$\frac{\text { Low RUP }}{\text { CON }}$} & \multicolumn{3}{|c|}{ High RUP } & & \multirow{2}{*}{ D } & \multirow{2}{*}{$\mathbf{L}$} & \multirow{2}{*}{$\mathbf{Q}$} & \multirow{2}{*}{$\begin{array}{l}\text { CON vs } \\
\text { NDF270 }\end{array}$} \\
\hline & & NDF270 & NF245 & NDF220 & & & & & \\
\hline Moisture & 614 & 593 & 595 & 592 & 13.0 & 0.19 & 0.11 & 0.14 & 0.57 \\
\hline Crude protein & $152^{c}$ & $167^{\mathrm{a}}$ & $165^{\mathrm{ab}}$ & $155^{b c}$ & 4.1 & 0.009 & 0.022 & 0.35 & 0.004 \\
\hline Ether extract & 217 & 232 & 225 & 240 & 11.2 & 0.23 & 0.005 & 0.015 & 0.20 \\
\hline Ash & 7.17 & 7.70 & 6.92 & 6.15 & 0.55 & 0.097 & 0.023 & 1.00 & 0.36 \\
\hline
\end{tabular}

${ }^{\dagger}$ Lambs received diets containing three levels of NDF: 270 (NDF270), 245 (NDF245), and 220 (NDF220) g/kg DM with 66.6 g/kg of RUP based on dry matter (DM); whereas control (CON) lambs were fed a diet with $270 \mathrm{~g} / \mathrm{kg}$ of NDF and $59.6 \mathrm{~g} / \mathrm{kg}$ of RUP (DM basis) for 56 days. ${ }^{\S}$ SEM, standard error of the means. ${ }^{+}$Least square means within a row with different superscripts $(\mathrm{a}-\mathrm{c})$ differ $(p<0.05)$. Linear $(\mathrm{L})$ and quadratic (Q) effects for the three treatments diets (NDF270, NDF245, and NDF220); D, diet.

\section{Discussion}

Balancing fiber nutrition is of crucial importance for effective production and health in ruminants. Previous studies suggested that production-restricting effects of high dietary fiber levels could potentially be alleviated by simultaneous inclusion of high concentrations of RUP [15]. However, the desirable level of NDF is not well determined at such high RUP levels for growing-finishing lambs with accelerated growth. Therefore, the present 
study investigated the effects of the inclusion of high dietary RUP levels and the effects of decreasing NDF levels at concurrently high RUP levels in growing-finishing Afshari lambs. To understand the results, it is important to consider that the NDF concentrations provided in the present study were not extreme values but practically relevant, considering that SRNS suggests an optimum dietary NDF concentration of 200-245 g/ $\mathrm{kg}$ DM for sheep and goats.

The results showed that DMI was not affected by RUP concentration but decreased linearly when offering decreasing levels of NDF at concurrently high RUP concentrations. The lower DMI in lambs fed the NDF220 diet is likely related to this diet's higher energy content because DMI is regulated by NDF concentration and ruminal bulk fill and energy provision for hepatic oxidation [13,29]. Considering that metabolic energy intake across periods was almost identical in the four groups (18.6, 18.1, 18.8, and 18.2 MJ/d for CON, NDF270, NDF245, and NDF220, respectively), it is not surprising that dietary treatment had no effects on BW, ADG, body length, and withers height during the whole experimental period.

The linear decrease in DMI at constant ADG logically implied a linear decrease in FCR with decreasing NDF concentration, with significantly lower overall FCR in the lambs fed the NDF220 diet. In accordance with our study, Ozdogan et al. [30] reported that dietary NDF concentrations of 271, 241, and $132 \mathrm{~g} / \mathrm{kg}$, achieved by gradual exchange of corn for dietary olive cake and olive oil, tended to improve FCR of lambs, although changes of DMI and ADG were not significant in that study. The study of Gallo et al. [21] showed that feeding 250 compared to $150 \mathrm{~g} / \mathrm{kg}$ of NDF to finishing lambsdecreased DMI; however, changes in FCR were not significantly different, as were ADG and final BW. Considering the compatible results of our study and the two previous studies, irrespective of different dietary CP and RUP levels, it may be potentially generalized that lambs can maintain their growth rather well across the indicated range of dietary NDF concentrations by adapting DMI or feed conversion to the energy content of the diet. However, partly superior performance of our NDF245 group in the first 14 days of the trial may suggest that NDF levels of $245 \mathrm{~g} / \mathrm{kg}$ provide the optimal balance between acidosis risk at low NDF and intake restriction at high NDF, especially in younger animals.

The inclusion of high RUP was intended to decrease apparent protein digestibility in the rumen; however, apparent digestibility of $\mathrm{CP}$ and $\mathrm{DM}$ tended to decrease in the whole digestive tract when comparing diet NDF270 with CON. A significant depressing effect on the apparent digestibility of DM was evident when lowering NDF concentration from $245-220 \mathrm{~g} / \mathrm{kg}$ at high RUP. It is unlikely that this lower DM digestibility originated from a higher passage rate because the NDF220 group also had the lowest DMI. Therefore, the decreased DM digestibility for NDF220 might be due to the inclusion of the greatest proportion of cereal grains in this diet. This may reduce the $\mathrm{pH}$-sensitive cellulolytic bacterial population in the rumen, resulting in partial depression of fiber digestion [31]. In support of such a suggestion, Hejazi et al. [32] reported that apparent digestibility of DM was greater for lambs supplemented with highly digestible fiber compared to the control. Furthermore, the concentration of peNDF $>8$ in diet greatly influences the digestibility of DM and fiber components [33]. In Holstein heifers, the highest DM digestibility was noted at $135 \mathrm{~g} / \mathrm{kg}$ of dietary peNDF 8.0 with a tendency to decrease at the lower $(108 \mathrm{~g} / \mathrm{kg})$ or greater $(198 \mathrm{~g} / \mathrm{kg})$ concentration of peNDF $>8.0$ [34]. Partly divergent from our findings, Ahmad et al. [35] reported that feeding 230, 280, and $330 \mathrm{~g} / \mathrm{kg}$ of NDF did not affect DM and CP digestibility of buffaloes. Similar results were reported by Tjardes et al. [36], who conducted a trial on Holstein steers by feeding moderate and high fiber diets (338 and $500 \mathrm{~g} / \mathrm{kg}$ of NDF, respectively). However, our findings are inconsistent with findings from Fimbres et al. [37], who showed that DM digestibility decreased linearly by feeding 100, 200 , and $300 \mathrm{~g} / \mathrm{kg}$ of chopped hay in finishing lambs. The latter may potentially be a response to an increased passage rate of feed particles from the digestive tract, which could reduce the digestibility of DM components. 
The present study also monitored some key behavioral readouts. The only effect that was seen when increasing RUP from CON to NDF270 was a decrease in total ruminating time. Probably, this effect should not be overemphasized as it disappeared when normalizing ruminating time for DMI or NDF intakes, which were equal among these two groups. Furthermore, total ruminatingtime and chewing and resting times were all not changed when testing across all diets. However, total eating time, ruminating time, and the summarized chewing time increased linearly with decreasing dietary NDF inclusion when normalized to NDF intake and, regarding ruminating and chewing, also when normalized to DMI. This logically follows from the already discussed linear decreases in DMI from NDF270 to NDF220, implying even more aggravated decreases in dietary NDF intake from NDF270 to NDF220. It follows that decreases in NDF hadno negative effects on any chewing activity in the present study. The similarity in total eating time with concurrent decreases in DMI impliesfor the NDF220 group that these lambs spend more time choosing feed. According to previous studies [38,39], decreasing dietary peNDF at constant total NDF concentration increased DMI in ruminants. It is also well documented that decreasing forage particle size and peNDF decreases ruminating activity in dairy cows [40]. In our study, time of eating, ruminating, and chewing remained constant when NDF and peNDF decreased in parallel and was even increased when expressed as minutes per kilogram of NDF intake for the NDF220 diet. Fiber quality and particle size affect rumen fill. Sheep and goats can ruminate very fine particles that would escape rumination in cattle [2]. It has been suggested that behavioral changes associated with feeding behavior in ruminants may reflect an animal's ability to cope with changes in their nutritional environment [7]. In a recent study, goats adapted their feeding behavior to the fiber portion of the offered diet, with more ruminating when fiber content was lowered [9]. This suggests physiological adaptations apart from eating behavior that allows animals to deal with low-fiber diets, including epithelial morphology and function for improved absorption and metabolization of acids [5,6]. Behavioral adaptations to cope with acidotic diets are very important, although research in this area is scarce.

Nonsignificant changes in plasma concentrations of albumin, $\mathrm{Ca}$, and $\mathrm{P}$ were consistent with the study of Gallo et al. [21], using various concentrations of NDF in lambs. The significant decrease in blood urea nitrogen of lambs fed high RUP versus low RUP substantiates the functionality of our experimental design. A higher proportion of undegradable $\mathrm{CP}$ in the rumen results in lower ammonia concentrations in rumen and blood. This is followed by a lesser requirement for urea synthesis by the liver. Similarly, Akhtar et al. [41] reported that a higher level of dietary RUP resulted in decreased BUN of lambs. It has been shown that inappropriate increases in the dietary proportion of RUP can decrease ruminal ammonium concentration to theextent that it adversely influences ruminal fermentation [42]. Fermentation attributes were not evaluated in the present study. However, constant (NDF270 and NDF245) to higher plasma concentrations of glucose (NDF220) in the high RUP groups and performance data argue against compromised fermentation in the present study. The even increased plasma glucose concentration in NDF220 lambs agreed with Zhao et al. [43], who reported that a lower concentration of NDF increased plasma glucose concentration in dairy cows.

Analyzing the slaughtering data showed that feeding diets with different concentrations of NDF along with high RUP did not change most of the carcass traits. Nonetheless, decreasing levels of dietary NDF increased HCW and hot dressing percentages linearly. This is coherent with the findings of Silva Moura et al. [44], where a lower proportion of roughage in the diet resulted in heavier SBW, HCW, and CCW in feedlot lambs. In a study ofSantos-Silva et al. [45], however, SBW, HCW, and CCW of lambs were not influenced by various levels of dietary NDF. Taking several earlier studies together, the effects of different concentrations of dietary fiber show variable results on carcass parameters in lambs $[21,30,45]$.

The weights of non-carcass parts (not shown in detail) like pelt, head, heart, liver, spleen, empty gut, and total non-carcass parts of lambs were not affected by different 
dietary NDF. Papi et al. [1] observed that decreasing dietary forage levels did not affect skin, head, kidney, lung, and spleen weights but changed feet, heart, and liver weights in growing fat-tailed lambs. In a study bySilva Moura et al. [44], lambs fed on a high-roughage diet had lighter empty gastrointestinal tract weight, empty body weight, and internal fat.

Diets did not affect carcass cuts, except for NDF245 lambs that tended to have heavier legs and fat tails. Preziuso et al. [46] observed heavier leg and shoulder weights in lambs on concentrate plus lucerne hay relative to concentrate only. In contrast, Moron-Fuenmayor and Clavero [47] reported lighter loin, leg, and shoulder weights in lambs on pasture grass relative to pasture grass plus concentrate. However, Papi et al. [1] reported that decreasing the forage level of diet did not affect the weights of most carcass cuts, but tail fat weight decreased for lambs fed a higher proportion of dietary forage. Silva Moura et al. [44] reported that a high dietary proportion of forage did not change the weights of feedlot sheep's shoulders, rib, loin, and leg.

Inconsistent with Silva Moura et al. [44], decreasing dietary NDF concentration had no effect on the moisture percentage of deboned carcasses, which was likely because of no differences in slaughter weight obtained with the present diets. Crude protein concentration in deboned carcasses decreased linearly with decreasing NDF concentrations, whereas ether extract changed quadratically with the highest values in NDF220. This indicates gradual changes in carcass composition that may include a higher proportion of carcass fat in NDF220. With quadratic changes in fat tail weight and total internal organ fat with highest values in NDF245, it may be speculated that decreasing NDF concentration leads to slightly higher body fat accretion in certain adipose depots, excluding backfat. The observed change in carcass $\mathrm{CP}$ concentration is consistent with findings of Ebrahimi et al. [48], who reported a decrease in crude protein percentage of LDM of growing lambs upon offering a high level of concentrate (11.3 MJ ME/ kg DM). Vice versa, Crouse et al. [49] showed that decreasing dietary concentrate intake led to increased $\mathrm{CP}$ concentrations of ram lamb carcass. Taken together, the benefits of linear increases in HCW obtained by decreasing dietary NDF concentration on a quantitative level were partly counteracted by lower carcass $\mathrm{CP}$ concentrations on a qualitative level. This conforms with a concept that the extent and form of energy intake may adjust the partitioning of energy utilization for protein and lipids synthesis or development of muscle and fat tissues [50,51].

Another very important finding was that the increase in RUP from CON to NDF270 increased carcass $\mathrm{CP}$ concentration. This highlights that the observed trend for lower apparent $\mathrm{CP}$ digestibility in the gastrointestinal tract and the lower plasma urea concentration of NDF270 compared to CON were indeed associated with improved CP accretion. Towards slaughter age (days 42 and 56), a redistribution of LDM area and BFT appeared to occur between CON and NDF270, where BFT was increased, and LDM area was decreased in the NDF270 group compared to CON. However, based on the overall improved carcass $\mathrm{CP}$ content, this finding is likely not an indication for increased fat and decreased protein accretion in NDF270 animals towards the end of the experimental period, which is further supported by a trend for lower fat-tail weight in NDF270 sheep compared to CON. Dietary NDF concentration did not affect BFT and LDM area, which is concordant with results from Flores-Mar et al. [20]. In contrast, Papi et al. [1] identified increased BFT with decreasing forage levels in fat-tailed lambs without affectingthe LDM area.

\section{Conclusions}

The present study identified that increasing the proportion of RUP within dietary CP has no effect on growth performance but leads to decreased plasma urea concentrations and increased carcass protein concentration. This can be interpreted as improved protein accretion despite a trend for lower apparent digestibility of dietary $\mathrm{CP}$ and DM. The present study further demonstrated that reducing NDF concentration of a high-RUP ration from $270-220 \mathrm{~g} / \mathrm{kg}$ DM causes a decrease in DMI that compensates the increased energy density of the ration, thereby maintaining growth rate and improving FCR. A slight increase in hot carcass weight at lower dietary NDF concentration was coupled to decreased carcass 
protein accretion and, potentially, higher body fat deposition. Another key finding was that decreasing dietary NDF and peNDF concentration at high RUP had no negative effects on times spent eating, ruminating, and chewing; those times even increased when expressed as minutes per kilogram of NDF intake. The current findings imply that reducing dietary NDF content of finishing rations to $220 \mathrm{~g}$ NDF $/ \mathrm{kg}$ DM at concurrently high RUP $/ \mathrm{kg}$ has no effects on eating behavior, minor effects on carcass composition, and overall improvement of feed conversion.

Author Contributions: Conceptualization, H.M.-A.; Methodology, H.M.-A., H.A., A.B.; Supervision, H.M.-A.; Writing—original draft, H.M.-A., A.A.; Writing—review and editing, H.M.-A., A.K.P., J.R.A.; Project administration, H.M.-A.; Funding acquisition, H.M.-A.; Data Curation, A.B.; Formal analysis, A.A., A.K.P., J.R.A.; Resources, H.A. All authors have read and agreed to the published version of the manuscript.

Funding: The study was funded by the Department of Animal Science, University of Zanjan, and the Ministry of Science, Iran.

Institutional Review Board Statement: The Animal Care and Welfare Committee (ID 1353) at the University of Zanjan, Iran approved the experimental and management protocols of this study.

Informed Consent Statement: Not applicable.

Data Availability Statement: The data presented in this study are available on request from the corresponding author.

Acknowledgments: We cordially thank the employees of the Sheep Research Farm of the University of Zanjan for diligent help with animal care.

Conflicts of Interest: There are no conflicts of interest with any of the data presented.

\section{References}

1. Papi, N.; Mostafa-Tehrani, A.; Amanlou, H.; Memarian, M. Effects of dietary forage-to-concentrate ratios on performance and carcass characteristics of growing fat-tailed lambs. Anim. Feed. Sci. Technol. 2010, 163, 93-98. [CrossRef]

2. Cannas, A.; Tedeschi, L.O.; Fox, D.G.; Pell, A.N.; Van Soest, P.J. A mechanistic model for predicting the nutrient requirements and feed biological values for sheep1. J. Anim. Sci. 2004, 82, 149-169. [CrossRef] [PubMed]

3. NRC. National Research Council. In Nutrient Requirements of Small Ruminants: Sheep-Goats-Cervids and New World Camelids, 7th Revised ed.; National Academy Press: Washington, DC, USA, 2007.

4. Cannas, A.; O Tedeschi, L.; Atzori, A.S.; Lunesu, M.F. How can nutrition models increase the production efficiency of sheep and goat operations? Anim. Front. 2019, 9, 33-44. [CrossRef]

5. Aschenbach, J.R.; Penner, G.B.; Stumpff, F.; Gäbel, G. RUMINANT NUTRITION SYMPOSIUM: Role of fermentation acid absorption in the regulation of ruminal pH12. J. Anim. Sci. 2011, 89, 1092-1107. [CrossRef] [PubMed]

6. Penner, G.B.; Steele, M.A.; Aschenbach, J.R.; McBride, B.W. Ruminant nutrition symposium: Molecular adaptation of ruminal epithelia to highly fermentable diets1. J. Anim. Sci. 2011, 89, 1108-1119. [CrossRef] [PubMed]

7. Neave, H.W.; Weary, D.M.; von Keyserlingk, M.A.G. Review: Individual variability in feeding behaviour of domesticated ruminants. Animal 2018, 12, s419-s430. [CrossRef] [PubMed]

8. Filho, J.R.; Tedeschi, L.; Cannas, A.; Vieira, R.; Rodrigues, M. Using the Small Ruminant Nutrition System to develop and evaluate an alternative approach to estimating the dry matter intake of goats when accounting for ruminal fiber stratification. J. Dairy Sci. 2014, 97, 7185-7196. [CrossRef]

9. Nielsen, B.; Cellier, M.; Duvaux-Ponter, C.; Giger-Reverdin, S. Dairy goats adjust their meal patterns to the fibre content of the diet. Animal 2021, 15, 100265. [CrossRef]

10. Galyean, M.; Hubbert, M. REVIEW: Traditional and alternative sources of fiber-Roughage values, effectiveness, and levels in starting and finishing diets 11 Substantial portions of this paper were presented at the 2012 Plains Nutrition Council Spring Conference and published in the conference proceedings (AREC 2012-26, Texas AgriLife Research and Extension Center, Amarillo). Prof. Anim. Sci. 2014, 30, 571-584. [CrossRef]

11. Gentry, W.W.; Weiss, C.P.; Meredith, C.M.; Brauer, C.L.; Mccollum, F.T.; Cole, N.A.; Jennings, J.S. 1406 Effects of roughage inclusion and particle size on performance and rumination behavior of finishing beef steers. J. Anim. Sci. 2016, 94, 4759-4770. [CrossRef]

12. Chibisa, G.E.; Beauchemin, K.A.; Koenig, K.M.; Penner, G.B. Optimum roughage proportion in barley-based feedlot cattle diets: Total tract nutrient digestibility, rumination, ruminal acidosis, short-chain fatty absorption, and gastrointestinal tract barrier function. J. Anim. Sci. 2020, 98, skaa160. [CrossRef] 
13. Allen, M.S. Review: Control of feed intake by hepatic oxidation in ruminant animals: Integration of homeostasis and homeorhesis. Animal 2020, 14, s55-s64. [CrossRef] [PubMed]

14. Firkins, J. Invited Review: Advances in rumen efficiency. Appl. Anim. Sci. 2021, 37, 388-403. [CrossRef]

15. Corea, E.; Castro-Montoya, J.; Mendoza, M.; López, F.; Martinez, A.; Alvarado, M.; Moreno, C.; Broderick, G.; Dickhoefer, U. Effect of forage source and dietary rumen-undegradable protein on nutrient use and growth in dairy heifers. Anim. Feed. Sci. Technol. 2020, 269, 114658. [CrossRef]

16. Broderick, G.A. Alfalfa Silage or Hay Versus Corn Silage as the Sole Forage for Lactating Dairy Cows. J. Dairy Sci. 1985, 68, 3262-3271. [CrossRef]

17. Eroderick, G.A. Relative Value of Fish Meal Versus Solvent Soybean Meal for Lactating Dairy Cows Fed Alfalfa Silage as Sole Forage. J. Dairy Sci. 1992, 75, 174-183. [CrossRef]

18. Smith, P.S. Dietary Fiber Requirements of Feedlot Lambs. Master's Thesis, University of the Free State, Bloemfontein, South Africa, 2008; p. 59.

19. Alhidary, I.A.; Abdelrahman, M.M.; Aljumaah, R.; Alyemni, A.H.; Ayadi, M.A.; Al-Saiady, M.Y. Rumen Discoloration of Growing Lambs Fed with Diets Containing Different Levels of Neutral Detergent Fibre. Pak. J. Zool. 2017, 49. [CrossRef]

20. Flores-Mar, J.; Zinn, R.A.; Salinas-Chavira, J. Influence of forage NDF level and source in growing-finishing diets on growth performance of feedlot lambs. Acta Agric. Scand. Sect. A Anim. Sci. 2017, 67, 134-138. [CrossRef]

21. Gallo, S.B.; Brochado, T.; Brandi, R.A.; Bueno, I.C.D.S.; Passareli, D.; Birgel, D.B.; Junior, E.H.B. Implications of low fiber levels in finishing lambs on performance, health, rumen, and carcass parameters. Trop. Anim. Health Prod. 2018, 51, 767-773. [CrossRef]

22. Mahjoubi, E.; Amanlou, H.; Mirzaei-Alamouti, H.R.; Aghaziarati, N.; Yazdi, M.H.; Noori, G.R.; Yuan, K.; Baumgard, L.H. The effect of cyclical and mild heat stress on productivity and metabolism in Afshari lambs1. J. Anim. Sci. 2014, 92, 1007-1014. [CrossRef]

23. Mirzaei-Alamouti, H.; Moradi, S.; Shahalizadeh, Z.; Razavian, M.; Amanlou, H.; Harkinezhad, T.; Anarkooli, I.J.; Deiner, C.; Aschenbach, J.R. Both monensin and plant extract alter ruminal fermentation in sheep but only monensin affects the expression of genes involved in acid-base transport of the ruminal epithelium. Anim. Feed. Sci. Technol. 2016, 219, 132-143. [CrossRef]

24. Lammers, B.; Buckmaster, D.; Heinrichs, A. A Simple Method for the Analysis of Particle Sizes of Forage and Total Mixed Rations. J. Dairy Sci. 1996, 79, 922-928. [CrossRef]

25. Kononoff, P.; Heinrichs, A.; Buckmaster, D. Modification of the Penn State Forage and Total Mixed Ration Particle Separator and the Effects of Moisture Content on its Measurements. J. Dairy Sci. 2003, 86, 1858-1863. [CrossRef]

26. Van Keulen, J.; Young, B.A. Evaluation of Acid-Insoluble Ash as a Natural Marker in Ruminant Digestibility Studies. J. Anim. Sci. 1977, 44, 282-287. [CrossRef]

27. Aguilar-Hernández, E.; Chay-Canul, A.J.; Gómez-Vázquez, A.; Magaña-Monforte, J.G.; Rios, F.G.; Cruz-Hernández, A. Relationship of ultrasound measurements and carcass traits in Pelibuey ewes. J. Anim. Plant. Sci. 2016, 26, 325-330.

28. AOAC. Official Methods of Analysis of the Association of Official Agricultural Chemists, 17th ed.; AOAC International: Gaithersburg, MD, USA, 2003.

29. Mertens, D.R. Regulation of Forage Intake. In Forage Quality, Evaluation, and Utilization; American Society of Agronomy: Madison, WI, USA, 1994; pp. 450-493.

30. Ozdogan, M.; Ustundag, A.O.; Yarali, E. Effect of mixed feeds containing different levels of olive cake on fattening performance, carcass, meat quality and fatty acids of lambs. Trop. Anim. Health Prod. 2017, 49, 1631-1636. [CrossRef] [PubMed]

31. National Research Council. Nutrient Requirements of Dairy Cattle and Domestic Animals, 7th Revised ed.; National Academies Press: Washington, DC, USA, 2001.

32. Hejazi, S.; Fluharty, F.L.; Perley, J.E.; Loerch, S.C.; Lowe, G.D. Effects of corn processing and dietary fiber source on feedlot performance, visceral organ weight, diet digestibility, and nitrogen metabolism in lambs. J. Anim. Sci. 1999, 77, 507-515. [CrossRef]

33. Zebeli, Q.; Aschenbach, J.; Tafaj, M.; Boguhn, J.; Ametaj, B.; Drochner, W. Invited review: Role of physically effective fiber and estimation of dietary fiber adequacy in high-producing dairy cattle. J. Dairy Sci. 2012, 95, 1041-1056. [CrossRef]

34. Wang, H.; Chen, Q.; Chen, L.; Ge, R.; Wang, M.; Yu, L.; Zhang, J. Effects of dietary physically effective neutral detergent fiber content on the feeding behavior, digestibility, and growth of 8- to 10-month-old Holstein replacement heifers. J. Dairy Sci. 2017, 100, 1161-1169. [CrossRef]

35. Ahmad, S.; Jabbar, M.A.; Khalique, A.; Shahzad, S.F.; Ahmad, N.; Fiaz, M.; Younas, U. Effect of different levels of NDF on voluntary feed intake, dry matter digestibility and nutrients utilization in dry Nili Ravi buffaloes. J. Anim. Plant. Sci. 2014, 24, 1602-1605.

36. Tjardes, K.E.; Buskirk, D.D.; Allen, M.S.; Tempelman, R.; Bourquin, L.; Rust, S.R. Neutral detergent fiber concentration in corn silage influences dry matter intake, diet digestibility, and performance of Angus and Holstein steers2. J. Anim. Sci. 2002, 80, 841-846. [CrossRef] [PubMed]

37. Fimbres, H.; Kawas, J.; Hernández-Vidal, G.; Picón-Rubio, J.; Lu, C. Nutrient intake, digestibility, mastication and ruminal fermentation of lambs fed finishing ration with various forage levels. Small Rumin. Res. 2002, 43, 275-281. [CrossRef]

38. Beauchemin, K.A.; Yang, W.Z.; Penner, G.B. Effective Fiber for Dairy Diets. In Proceedings of the 67th Minnesota Nutrition Conference and University of Minnesota Research Update Session: Livestock Production in the New Millennium, St. Paul, MN, USA; 19-20 September 2006; pp. 107-119. 
39. Zhao, X.H.; Zhang, T.; Xu, M.; Yao, J.H. Effects of physically effective fiber on chewing activity, ruminal fermentation, and digestibility in goats1. J. Anim. Sci. 2011, 89, 501-509. [CrossRef]

40. Yansari, A.T.; Valizadeh, R.; Naserian, A.A.; Christensen, D.; Yu, P.; Shahroodi, F.E. Effects of Alfalfa Particle Size and Specific Gravity on Chewing Activity, Digestibility, and Performance of Holstein Dairy Cows. J. Dairy Sci. 2004, 87, 3912-3924. [CrossRef]

41. Akhtar, M.; Ali, M.; Hayat, Z.; Yaqoob, M.; Sarwar, M. Effect of Varying Levels of Dietary Ruminal Undegradable Protein on Feed Consumption and Growth Performance of Growing Kajli Lambs. Int. J. Agric. Biol. 2016, 969-974. [CrossRef]

42. Broderick, G.; Mertens, D.; Simons, R. Efficacy of Carbohydrate Sources for Milk Production by Cows Fed Diets Based on Alfalfa Silage. J. Dairy Sci. 2002, 85, 1767-1776. [CrossRef]

43. Zhao, M.; Bu, D.; Wang, J.; Zhou, X.; Zhu, D.; Zhang, T.; Niu, J.; Ma, L. Milk production and composition responds to dietary neutral detergent fiber and starch ratio in dairy cows. Anim. Sci. J. 2015, 87, 756-766. [CrossRef]

44. Moura, C.M.S.; Araújo, G.G.L.; Oliveira, B.Y.S.; Azevêdo, J.A.G.; Filho, E.C.P.; Azevedo, P.S.; Santos, E.M. Different roughage: Concentrate ratios and water supplies to feedlot lambs: Carcass characteristics and meat chemical composition. J. Agric. Sci. 2019, 157, 643-649. [CrossRef]

45. Santos-Silva, J.; Francisco, A.; Alves, S.P.; Portugal, P.; Dentinho, T.; Almeida, J.; Soldado, D.; Jerónimo, E.; Bessa, R.J. Effect of dietary neutral detergent fibre source on lambs growth, meat quality and biohydrogenation intermediates. Meat Sci. 2018, 147, 28-36. [CrossRef] [PubMed]

46. Preziuso, G.; Russo, C.; Casarosa, L.; Campodoni, G.; Piloni, S.; Cianci, D. Effect of diet energy source on weight gain and carcass characteristics of lambs. Small Rumin. Res. 1999, 33, 9-15. [CrossRef]

47. Moron-Fuenmayor, O.; Clavero, T. The effect of feeding system on carcass characteristics, non-carcass components and retail cut percentages of lambs. Small Rumin. Res. 1999, 34, 57-64. [CrossRef]

48. Ebrahimi, R.; Ahmadi, H.; Zamiri, M.; Rowghani, E. Effect of Energy and Protein Levels on Feedlot Performance and Carcass Characteristics of Mehraban Ram Lambs. Pak. J. Biol. Sci. 2007, 10, 1679-1684. [CrossRef] [PubMed]

49. Crouse, J.D.; Field, R.A.; Chant, J.L.; Ferrell, C.L.; Smith, G.M.; Harrison, V.L. Effect of Dietary Energy Intake on Carcass Composition and Palatability of Different Weight Carcasses from Ewe and Ram Lambs. J. Anim. Sci. 1978, 47, $1207-1218$. [CrossRef]

50. Oddy, V. Regulation of muscle protein metabolism in sheep and lambs: Nutritional, endocrine and genetic aspects. Aust. J. Agric. Res. 1993, 44, 901-913. [CrossRef]

51. Hocquette, J.-F.; Ortigues-Marty, I.; Pethick, D.; Herpin, P.; Fernandez, X. Nutritional and hormonal regulation of energy metabolism in skeletal muscles of meat-producing animals. Livest. Prod. Sci. 1998, 56, 115-143. [CrossRef] 